\title{
O século XX pelas descobertas da Medicina
}

José da Rocha Carvalbeiro

$\mathrm{O}_{\mathrm{r}}^{\mathrm{i}}$ LIVRo é bem escrito e sua leitura, um regalo, primeira observação que poderia encerrar esta resenha.

Um crítico literário, num suplemento de jornal, afirma que é maldição perder o prazer da leitura pela atitude profissional instintiva de analisar o texto. Tentava, lendo por lazer, ludibriar a técnica de análise crítica e concluía que ficar no meio do caminho é o pior dos mundos: ler sem profundidade de análise e sem prazer.

Afinal, que tom deve ter uma resenha? Pesquisadores alheios aos meandros literários, estamos habituados com resumos de teses e de artigos científicos. Fazemos algumas resenhas de livros científicos, evitando dar-lhes tom de arguição. A dificuldade é maior num livro dessa natureza, que exibe, em paralelo, a história de um século e de suas conquistas científicas na área da saúde, o que não é pouco.

Assinalo, de início, que o contexto científico atual associa desenvolvimento (econômico e social) com qualidade de vida. E essa com os avanços da ciência, da tecnologia e da inovação, o que está implícito no plano desta obra e explícito na sua "Apresentação".

A obra situa-se numa zona de fronteira: os autores elegem fatos científicos, a seu juízo marcantes em determinado período; transitam pelas suas origens (muitas vezes anteriores a esse período), pelo seu desenvolvimento e pelos ambientes, próximo e contextual, em que o processo se deu. A linguagem acompanha a complexa relação entre esses dois ambientes e atende, simultaneamente, as maneiras próprias do ambiente científico (esotérico) e do ambiente culto (exotérico) de quem "ama a ciência, não sendo dela um profissional” (Vogt, 2014). Essa afirmação remete à espiral da cultura cientifica, de Carlos Vogt, coordenador do Laboratório de Estudos Avançados em Jornalismo (Labjor), da Unicamp, onde se cultuam as diversas maneiras de comunicar fatos científicos. O que ajuda a descobrir, afinal, o que é esse livro: o que de científico e o que de anedótico se escondem nos capítulos.

Para curtir o anedótico e identificar a coerência do caminho científico, optamos por abandonar, na espiral de Vogt, os quadrantes do ambiente esotérico: o primeiro (produção e difusão científicas) e o segundo (ensino da ciência e formação de cientistas). Admitimos que essa obra está, no ambiente exotérico, entre os quadrantes terceiro (ensino para a ciência) e quarto (divulgação científica). Com isso, o livro foge à linguagem especializada para atingir um público muito mais amplo. E o faz com sucesso, aparente a meu juízo.

Considero essa uma obra de divulgação científica e evito, assim, uma análise científica. Até porque, não domino, cientificamente, todos os temas escolhidos pelos autores, e lembro o crítico: deixaria de ter prazer na leitura, ao enveredar pela crítica "literário-científica".

Em primeiro lugar, sem discordar da escolha, penso em maneiras alternativas de eleger temas científicos considerados 
relevantes no período. A última virada de século coincidiu com mudança de milênio, com inúmeras celebrações. Alguns místicos previram o fim do mundo, que de certa forma foi traduzido no mundo moderno das TIC pelo pavor, injustificado, de caos total no sistema informático ("bug do milênio"). Em todas as áreas da vida social fizeram-se resenhas de eventos importantes. Não faltou um levantamento, por uma prestigiada revista científica de medicina (NEJM) das conquistas do milênio: "Olhando para trás, o milênio na medicina" (The Editors, 2000). Considerando que, até o Renascimento, muito pouco havia de "verdadeiramente científico", uma simplificação recente (MedicineNet, 2014) limita o período aos "últimos 500 anos". Fica evidente que o mais importante está limitado ao século XX e concentrado nas suas últimas décadas. Mostram-se as descobertas em ordem cronológica, identificando a origem temporal dos fatos científicos e assinalando sempre os avanços mais recentes. A simplificação para quinhentos anos começa, portanto, no século XVI, com a "elucidação da anatomia humana". Mas, nesse mesmo item, incluem-se avanços tão recentes quanto a cirurgia de coração aberto.

São onze os itens considerados pelo NEJM: Elucidação da Anatomia e da fisiologia humanas; Descoberta das células e suas subestruturas; Elucidação da química da vida; Aplicação da estatística na medicina; Desenvolvimento da anestesia; Descoberta da relação de micróbios com doenças; Elucidação de herança e da genética; Conhecimento do sistema imunológico; Desenvolvimento da body imaging; Descoberta dos agentes antimicrobianos; Desenvolvimento de farmacoterapia molecular.
Comparamos o plano dessa obra em resenha com o desenvolvimento da medicina no milênio anterior (ou dos quinhentos anos). Sem muito esforço, podemos incluir nos onze itens resenhados pelos editores do NEJM os assuntos tratados nos 21 capítulos desse livro e, até mesmo, no vigésimo segundo que já avança pelo século XXI. São eles: Febre amarela; Luvas e infecção; Eugenia, cromossomas e genes; Transplantes; Raquitismo e vitamina $\mathrm{D}$; Diabetes e insulina; Raio X e radiologia; Antibióticos e ética na pesquisa; Escorbuto, tuberculose, cítricos, antibióticos, ensaio clínico; Poluição do ar, fog e smog, fumo de cigarro, doenças respiratórias e câncer de pulmão; Câncer do colo do útero, Papanicolaou, LSD e tortura; Pílula anticoncepcional; Câncer e quimioterapia; Cirurgia torácica e transplantes; Transfusão sanguínea e hepatite viral; Imagem: ultrassom e tomografia; Vacinas e soroterapia; Fecundação assistida; Intoxicação pelo chumbo; Aterosclerose; HIV/Aids; Século XXI: projeto Genoma Humano e quimioterapia personalizada.

É notável a "Conclusão dos Editores" do NEJM: O tratamento eficaz e a prevenção da doença "aumentou a expectativa de vida e reduziu a incapacidade além das esperanças mais otimistas dos médicos até algumas décadas atrás - $\mathrm{e}$ muito além dos sonhos de seus antecessores de mil anos atrás. Nós não somos mais capazes do que eles eram de prever o que este novo milênio nos trará". Os autores dessa obra parecem concordar e afirmam, no último parágrafo da Introdução: "Hoje, a ciência esmiúça as bases moleculares do DNA para prever o aparecimento de doenças e cânceres, para direcionar a descoberta de novos medicamentos contra doenças antigas $\mathrm{e}$ 


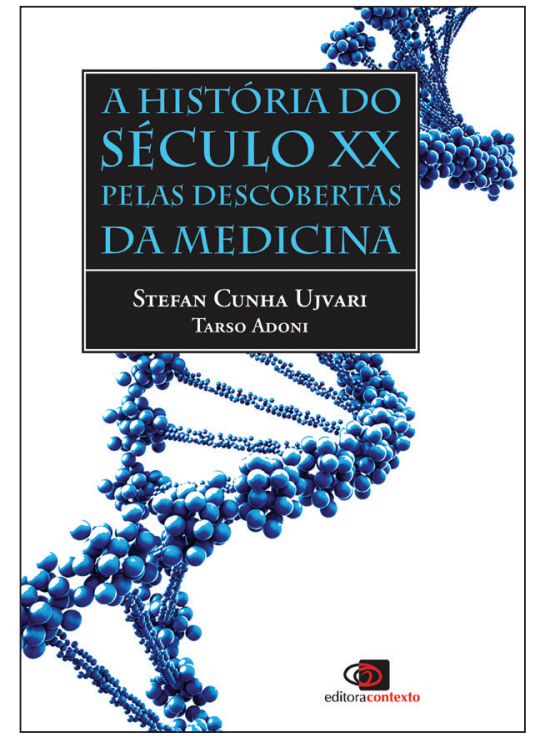

UJVARI, S. C; ADONI, T. A bistória do século $X X$ pelas descobertas da Medicina.

São Paulo: Contexto, 2014. 320p.

para escolher melhores opções de tratamento. Talvez estejamos testemunhando o nascimento de uma nova era que, no futuro, venha a se chamar 'século da genética"”. Nada tão profético quanto essas duas considerações.

A contribuição desse livro é fantástica, como já assinalado, apresentando um texto acessível, em português corrente, ao que consideramos (com Carlos Vogt) o meio exotérico, ou ambiente culto de quem "ama a ciência, não sendo dela um profissional".

Embora seja um texto em português (norma culta), a bibliografia citada pelos autores é majoritariamente internacional. São, ao todo, 337 referências, quase todas em inglês, e apenas 57 (17\%) em português. Essas, quase sempre, são traduções de obras estrangeiras. Em sete dos 26 capítulos não há uma única referência em português. São em média treze referências por capítulo que, como não podia deixar de ser, cobrem um período de mais de um século, de 1902 a 2013.

A opção por consulta preferencial a obras estrangeiras dá ao livro um viés, comum na área científica. É relativamente nova a prática de classificar os autores, seus artigos e os periódicos onde são publicados. Muito valorizada no ambiente acadêmico, leva ao extremo de criar um instrumento (Qualis da Capes) de classificação dos programas de pós-graduação no país. As revistas estrangeiras, especialmente as editadas em inglês, ocupam sistematicamente os primeiros lugares. Assim, não estamos expressando juízo crítico a respeito da marcada preferência dos autores por referir publicações estrangeiras, em inglês.

Com essa decisão de valorizar bibliografia majoritariamente estrangeira, deixaram de incluir contribuições nacionais que poderiam enriquecer a obra. Uma consulta à coleção SciELO (Scientific Electronic Library Online) identifica alguns exemplos dos avanços que também tiveram destaque na produção local.

No capítulo relacionado com a Febre amarela encontramos no periódico da Casa de Oswaldo Cruz abordagem de como Lutz e Ribas ajudaram a provar que as estegomias transmitem o vírus amarílico:

Experiências, realizadas no Hospital de Isolamento de São Paulo em duas etapas: na primeira, entre dezembro de 1902 e janeiro de 1903, seis voluntários - três brasileiros, um italiano e os próprios Ribas e Lutz - deixaram-se picar sucessivas vezes por mosquitos infectados; na segunda, entre abril e maio de 1903, três voluntários, imigrantes italianos recém-chegados ao Brasil, dormiram 
com lençóis e roupas manchadas e infectadas pelo sangue e vômito de doentes, num quarto vedado para que não entrasse nenhum mosquito e com uma estufa para que o recinto permanecesse constantemente calorento, evitando assim a contra-argumentação de que a queda brusca de temperatura fosse capaz de destruir os miasmas da febre amarela. (Almeida, 2000)

Estudos Avançados (IEA/USP) poderia ajudar a ilustrar o capítulo de HIV/ Aids e do coquetel de medicamentos antivirais. Encontramos o artigo de Mirko Grmek, um expoente na área de história e epistemologia das ciências da saúde: "O enigma do aparecimento da Aids", com explicação absolutamente original, de inspiração neodarwiniana completada pelo conceito de patocenose - criado pelo autor - que permite relacionar o princípio dessa epidemia com as mudanças ocorridas na morbidade geral (Grmek, 1995).

Ainda no capítulo de HIV/Aids, tenho a ousadia de mencionar artigo publicado em Estudos Avançados sobre ocorrências inusitadas no XI Congresso Internacional de Aids, em Vancouver, em 1996:

O Congresso foi marcado, desde a sessão de abertura até a de encerramento, pelo protesto dos ativistas das ONGs, notadamente os diversos Act Up de Nova York, Golden Gate e Philadelphia. O principal alvo foi a ganância (greed) dos laboratórios farmacêuticos e os preços exorbitantes dos medicamentos reunidos em esquema (coquetel), no qual se depositavam as esperanças de maior sobrevida para as pessoas vivendo com HIV. Associavam com ênfase a ganância à morte, gritando palavras de ordem e distribuindo panfletos com a mensagem incisiva: greed $=$ death. Os ativistas literalmente destruíram os quiosques de propaganda dos laboratórios farmacêuticos, instalados no recinto do congresso. Era motivo de expectativa de todos saber qual seria o alvo de cada dia: ao iniciar-se a movimentação, com apitaço, todos se deslocavam atrás dos ativistas até que se chegava ao laboratório escolhido. O Congresso culminou, na sessão de encerramento, com sonora vaia, não apenas dos ativistas mas da quase totalidade do plenário, ao representante da instituição promotora, a International Aids Society. Este anunciou, como grande conquista, ter conseguido dos laboratórios farmacêuticos a garantia de que tratariam todos os participantes de ensaios clínicos de drogas cuja eficácia se conseguisse comprovar. Mesmo os participantes dos grupos-controle receberiam a nova droga, após a conclusão do estudo. (Carvalheiro, 1997)

Essa autocitação traduz a ideia de que falta à obra uma ênfase nas consequências finais da introdução de inovações na medicina que analise, além da eficácia, também a efetividade. Sem o que, ficaremos reféns dos interesses da bigPharma que se esforça por impor a ideia de inovação como "uma invenção com nota fiscal". O contraponto, a ideia generosa de "Atenção Primária em Saúde", define que "num sistema universal de saúde, inovação é acesso".

Em conclusão, recomendo a leitura dessa obra. Que oferece o prazer de desfrutar da saga em que a aparente linearidade da produção científica esconde instigantes embates sociais em seus meandros. Os limites que assinalei são 


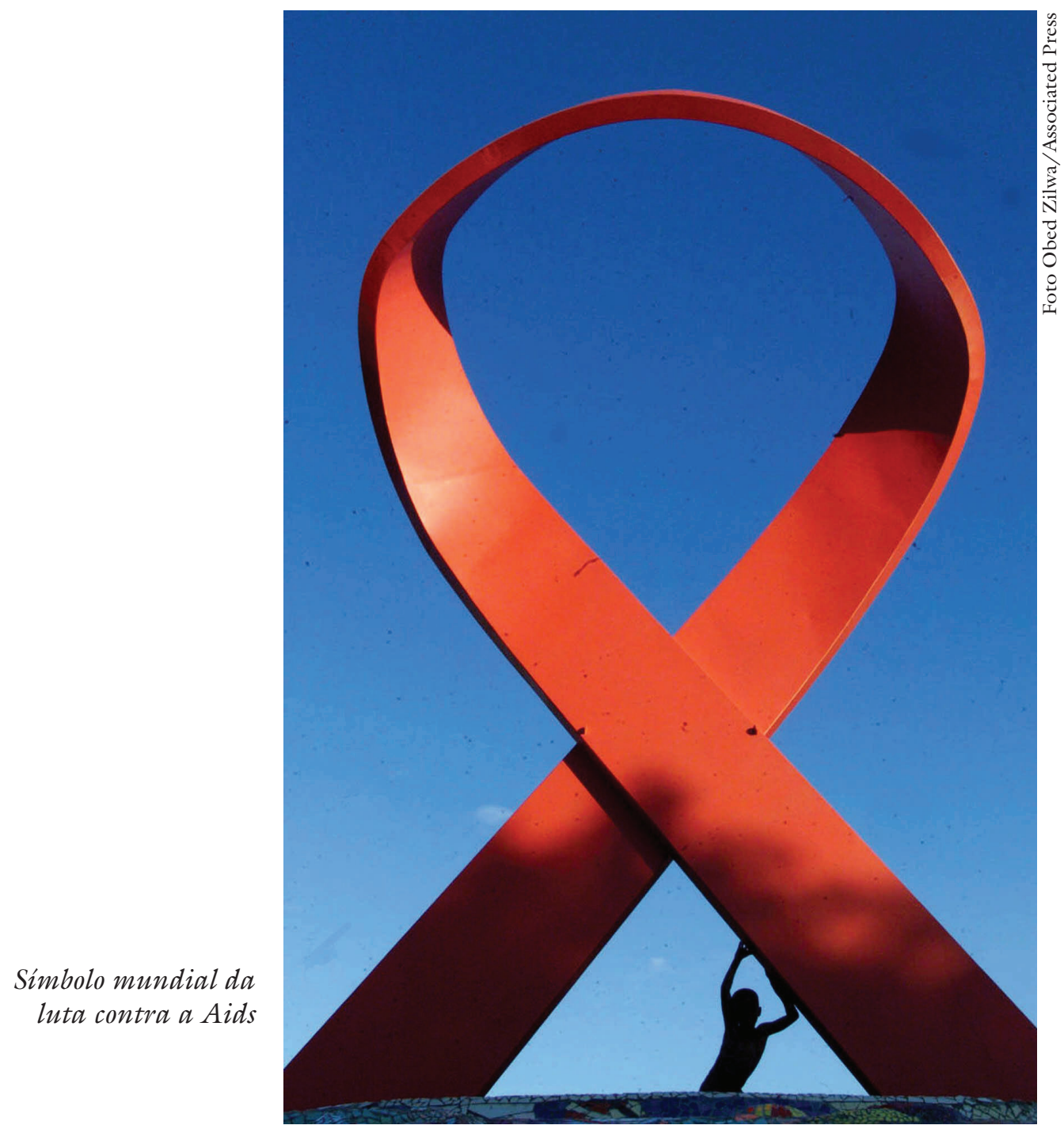

apenas de sugestão para uma nova edição, ou um desafio aos autores, que demonstram maestria na arte de descrever as maneiras como se deram os avanços, com a implícita translação entre a bancada e a beira do leito (medicina translacional). Assumam a marcada tendência atual do que se chama sinteticamente K4A (knowledge for action) ou "medicina translacional plus", que analisa como tornar disponíveis os avanços científicos (invenções) à população num sistema universal como o SUS (inovação verdadeira).

\section{Referências}

ALMEIDA, M. de. Combates sanitários e embates científicos: Emílio Ribas e a febre amarela em São Paulo. Hist. cienc. saude-Manguinhos, Rio de Janeiro, v.6, n.3, nov. 1999/fev. 2000.

CARVAlHeiro, J. da R. A vacina da Aids, a quimera e a vaca gorda. Estud. Av., v.11, n.31, p.191-209, 1997.

GRMEK, M. O enigma do aparecimento da Aids. Estud. Av., v.9, n.24, p.229-39, 1995.

MEDICINENet, Medical Milestones 
- The Past 500 Years. Disponível em: <http://www.medicinenet.com/script/ main/art.asp?articlekey $=12579>$ Acesso em: 20 jul. 2014

THE EDITORS. Looking back on the millennium in medicine. New Engl J Med, v.342, p.42-9, 2000

VOGT, C. Ciência, linguagem e literatura. Editorial. ComCiência, Revista Eletrônica de Jornalismo Científico, 10 jul. 2014. Disponível em: <http://www.comciencia. $\mathrm{br} /$ comciencia $/$ ?section $=8 \&$ edicao $=101$ \&id=1234> Acesso em 20 jul. 2014.

José da Rocha Carvalheiro é médico e professor titular de Medicina Social da Faculdade de Medicina de Ribeirão Preto da USP. Foi colaborador-pleno do Instituto de Estudos Avançados da USP.

@-jrcarval@fiocruz.br

${ }^{\text {I }}$ Faculdade de Medicina de Ribeirão Preto, Universidade de São Paulo/SP, Brasil. 